UDC 336.1

DOI: https://doi.org/10.32782/2224-6282/169-12

\author{
Kluchnyk Lilia \\ Senior engineer \\ SI "Institute of Regional Research named after M. I. Dolishniy \\ of National Academy of Sciences of Ukraine"
}

Ключник Л. В.

ДУ «Інститут регіональних досліджень імені М. І. Долішнього Національної академії наук України»

\title{
INVESTMENT FORMATION OF THE HOUSEHOLDS OF UKRAINE
}

The article deals with the development of the households of Ukraine. It is investigated that the study of households as an institutional unit, which is the least studied category, is important for the national economy. The article clarifies the essence of households in the system of market relations. The components of the household budget are indicated and the possibilities of using the household budget as an investment tool are considered. It is emphasized that the result of the functioning of households as independent subjects of the market economy is the formation of savings, which, in turn, is a powerful investment tool. The growth rates of cash incomes, expenditures, and savings of households in Ukraine are estimated.

Keywords: households, investments, economics, budget, savings.

JEL classification: $H 31$, G51

\section{ІНВЕСТИЦЙНЕ ФОРМУВАННЯ ДОМОГОСПОДАРСТВ УКРӒ̈НИ}

Стаття присвячена розвитку сектору домогосподарств в Україні. Досліджено, щуо важливе значення для національної економіки має дослідження домогосподарств як інституиіийної одинииі, щь є найменш дослідженою категорією. У статті з'ясовано сутність домогосподарств у системі ринкових відносин. Зазначено складові бюджету домогосподарств та розглянуто можливості застосування бюджету домогосподарства як інвестиційного інструменту. Наголошено, щзо результатом функиіонування домогосподарств як самостійних суб'єктів ринкової економіки $\epsilon$ формування заощаджень, які, у свою чергу, є потужним інвестиційним інструментом. Оиінено темпи росту грошових доходів, видатків, заощаджень домашніх господарств в Україні. Порівняно величини доходів і витрат, які припадають на одне домашнє господарство в Украӥні та в європейських державах, щьо свідчить про неможливість співставлення результатів, оскільки вони функиіонують в різних системах і умовах. Аналізовано структуру грошових доходів і сукупних ресурсів домогосподарств в Україні.

Ключові слова: домогосподарства, інвестииії, економіка, бюджет, заощадження.

Formulation of the problem. The investment potential is one of the most important aspects that create opportunities for economic development of Ukraine. In view of the low trend of attracting foreign investment in the country's development, the main problems today are the search for additional sources of funding. Therefore, it is the use of the investment potential of households that is a priority source of domestic investment. In our opinion, the creation of conditions that ensure the formation of investment potential creates a number of prerequisites for the implementation of effective investment policy in the national economy.

Analysis of recent research and publication. The researching of household of Ukraine devoted to the works of domestic and foreign scientists: L. Abalkin, D. Chernykov, L. Dobryk, I. Karapeyichyk, S. Kladchenko, S. Kravchenko, O. Mizina. They proved the importance of household in the economy at the national, sectoral and regional levels, the creation of attractive and favorable conditions for investment in this area. At the same time, methodological approaches are insufficiently developed and the evaluation of the household sector from the point of view of investments is analyzed. Practical undisclosed issues of investment evaluation of household of Ukraine led to the choice of the topic of the article.

The purpose of the article is to given investment analysis of household of Ukraine.
Presenting main materials. Despite the significant number of households, which today is almost 15 million units (Figure 1), their financial resources and opportunities to ensure the effective development of the national economy remain insufficiently studied.

Given the change in the dynamics of the average size and number of households in 2000-2020, it becomes necessary to use a systematic approach. This direction will reveal the impact of the main problematic aspects that led to the reduction of their number.

The main indicators, according to which the results of their financial activities are analyzed, are as follows: the number of households, the number of persons in one household, income, expenses and savings of households (Figure 2, Figure 3).

As the data of Figure 2, savings made by households in the period 2005-2013 tend to increase, although in 2013 there was a decrease in savings compared to 2012 by UAH 31,014 million or $21 \%$. And in the period of 2014-2019 there is a significant decrease in household savings - in 2014 UAH 30.780 million. And for the first time in 15 years (study period) the value of the indicator in 2019 is negative and is -116165 million. $\mathrm{UAH}$, which is explained by the excess of expenditures over revenues and the increase in consumption in the current period, is provided by the savings of previous periods.

Such behavior of domestic households is largely due to unjustified increase in consumption and accumulation 


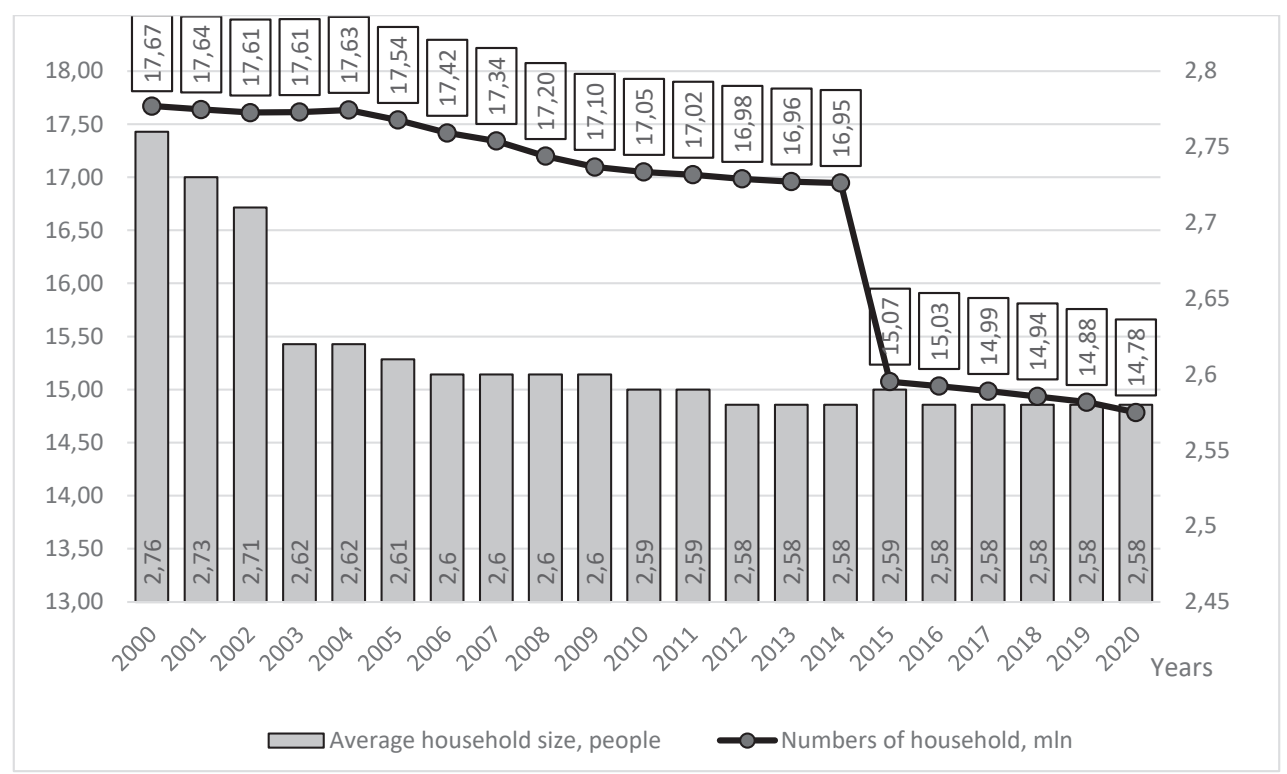

Figure 1. Dynamics of the average size and number of households in Ukraine in 2000-2020 Source: made of author [4]

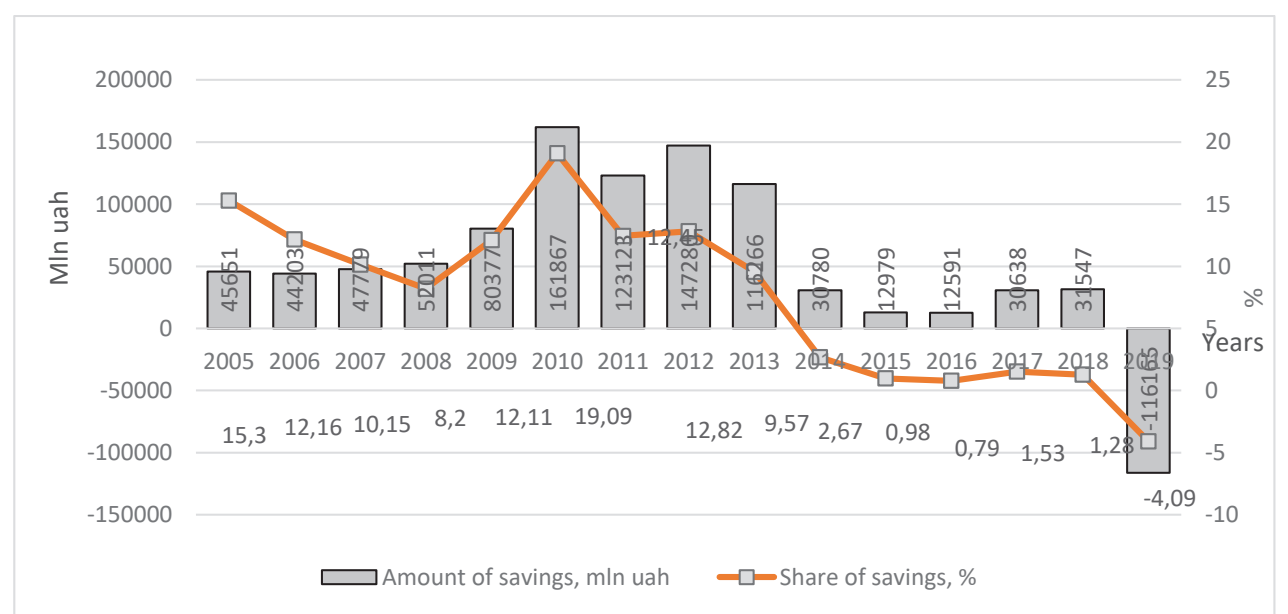

Figure 2. Dynamics of the volume and share of savings in the income of the population of Ukraine in 2005-2019 Source: made of author [4]

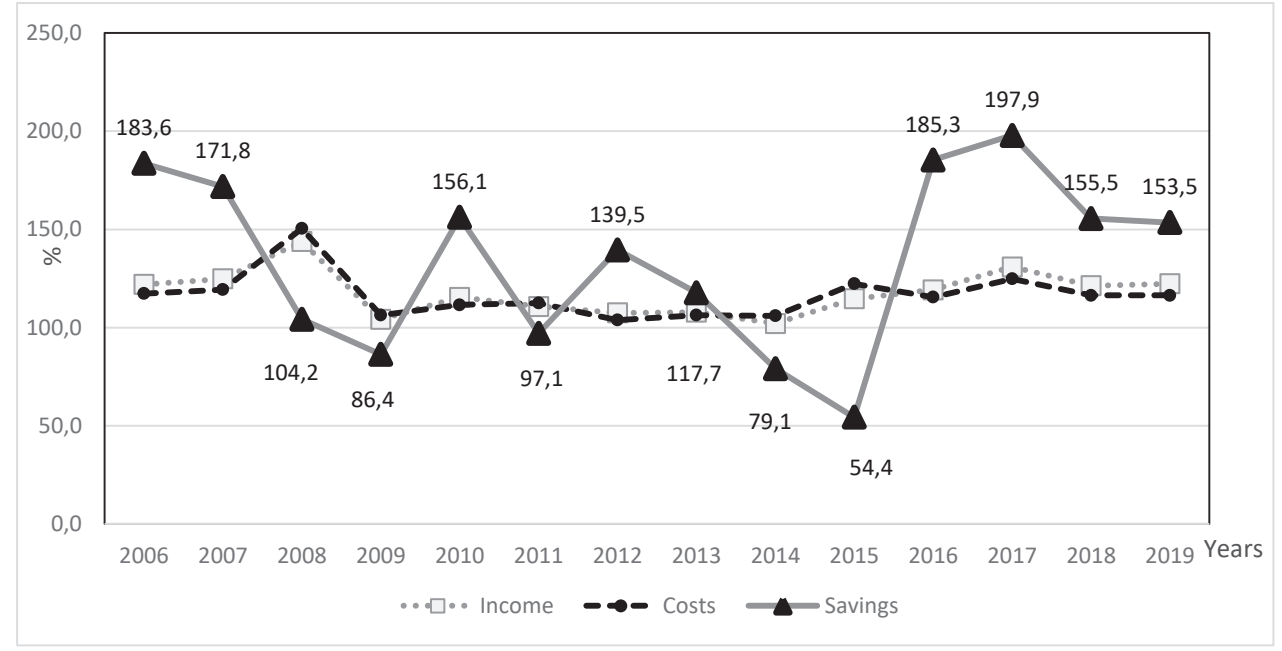

Figure 3. Growth rates of cash incomes, expenditures, household savings in Ukraine in 2006-2019, \% Source: made of author [1-4] 
$\frac{\sqrt[0]{0}}{\frac{\pi}{6}}$

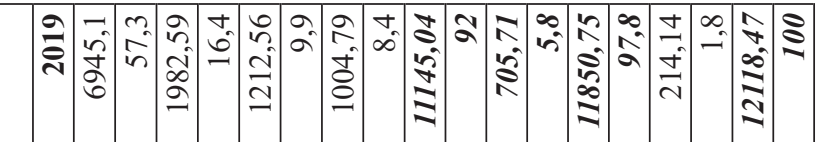

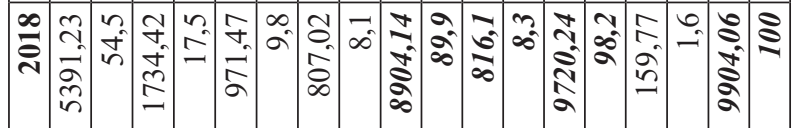

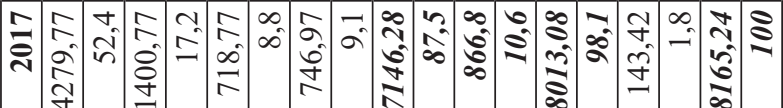

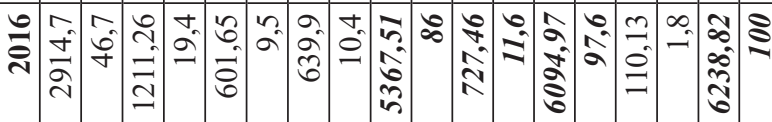
究

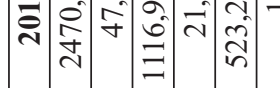
J

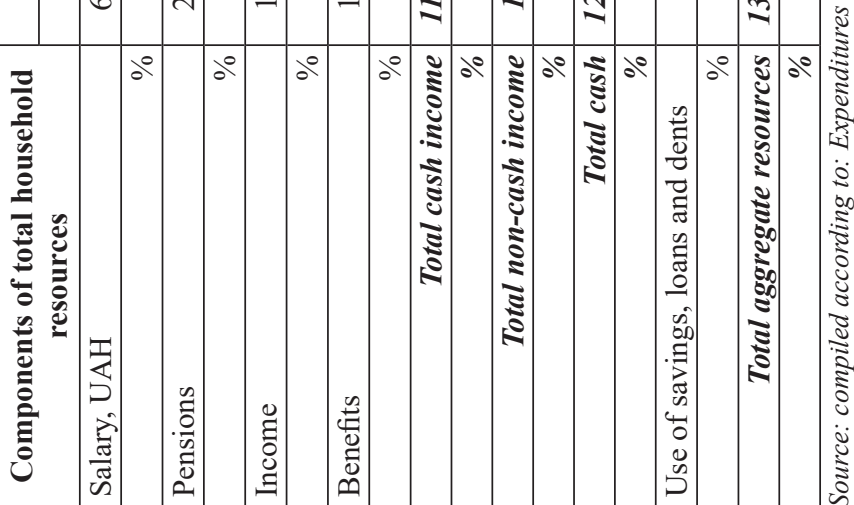

of non-financial assets. This was also due to expectations of negative situations and distrust of banking and non-banking financial institutions, rather than a decrease in household incomes. In the period 2015-2018, less than $2 \%$ of revenues were spent on savings and this indicator tends to decrease, and in 2019 it was $-4.09 \%$.

During the economic crises in the country, in particular, in 2008 (by 7.1\%) and in 2014 (by $12.63 \%$ ) compared to 2005 , the share of savings decreased significantly due to the devaluation of the hryvnia, significant price increases and rising costs for housing and communal services. At the same time, the total amount of resources owned by households did not decrease, but continued the dynamics of growth even in times of crisis.

For comparison, in the European Union in 2015, this figure ranged from $-1.5 \%$ in Denmark, $-0.5 \%$ - Estonia, $1 \%$ - Finland, $16.9 \%$ - Norway, $9.38 \%$ - Germany, $16.2 \%$ - Sweden to $19 \%$ in Switzerland, the share of savings in household income in the US in 2015 was 6\%, Canada $5.2 \%$, but because these countries have higher incomes, households in these countries save in absolute terms more. High savings are typically typical of high-income countries.

Assessing the overall financial results of households in Ukraine for the study period, it should be noted not only high growth rates of income and expenditure, but also outpacing growth rates of their savings (Table 1).

A comparison of the amount of income and expenditure per household in Ukraine and in European countries shows that it is impossible to compare the results, as they operate in different systems and conditions. It is important to study the structure of cash income and total resources of households on average per month per household.

As shown in table 1, in the structure of total financial resources of households, the largest share $(57.3 \%)$ in 2019 fell on wages. It is worth noting the increase in its share in total revenues for the analyzed period, and taking into account this, its value was UAH 6945.1 and increased 11.45 times compared to 2005. However, the level of wages in Ukraine is the lowest in Europe. According to experts, up to $40 \%$ of wages in Ukraine are paid in "envelopes", this part of wages is not taken into account in official statistics and underestimates the real situation in the field of wages of households.

In our opinion, the presence of problematic issues related to the increase in the share of wages in the household income is due to a significant tax burden on the wage fund of enterprises, lack of control over compliance with current legislation on wages and liability of officials for violating it.

In conditions of socio-economic instability, there are a number of problematic aspects of the formation of financial resources and their further involvement in investment processes, in particular in terms of optimizing the structure of household expenditures and ensuring an adequate level of income that would generate savings; use 
of tools that allow not only to save but also to increase financial resources. Household savings create financial resources less consumption costs.

The need to increase household incomes as participants in financial relations, to form financial resources and attract free funds to the economic cycle, necessitates a study of the impact of economic processes on the state of formation of household savings.

Household savings are classified according to the nature of mobilization: organized (financial assets of households stored in financial institutions: deposits, securities, insurance policies, etc.) and unorganized (cash savings stored directly with the population in national and foreign currency).

The presence of household savings in an organized form indicates that they are subjects of financial relations, because the formation of organized household savings occurs in cooperation with various institutions of the financial system and with the participation of other subjects of financial relations, which causes a wide range of financial instruments to make savings by the population and directly involve households in investment processes, ie the transformation of savings into an investment resource for the economy and the functioning of the household as an investor.

The share of household savings in GDP for the analyzed period ranged from 0.7 to $15 \%$. In 2010 , the share of savings increased by $9.5 \%$, despite a slight increase in GDP. The significant impact on the share of savings in the structure of GDP, the small crisis of 2014 . In the period 2014-2019, this figure decreased by $3 \%$ and in 2019 amounted to $-2.9 \%$. Such circumstances made it difficult to attract financial resources from households.

Factors related to the formation of household expenditures also have a significant impact on the dynamics of savings. Within the limits of the received net monetary incomes the population independently decides, what part of them and on what current needs to spend, and what - to save. Such decisions are made within an individual household, but freedom of choice in decision-making depends entirely on the income per person in a particular household.

It is worth noting that food expenditures have an objective level below which the household cannot fall. Therefore, such households abandon current savings and are forced to use past savings. Because savings are one of the main factors in shaping the investment potential of households, and can be an additional source of income.

Analyzing the growth rates of savings and deposits, it can be noted that the volume of deposits for the analyzed period was lower compared to savings. The dynamics of growth rates of savings and household deposits had the most negative trend, namely the negative value of indicators in 2009, 2014 and 2015.

This situation is explained by the fact that accumulations tend to decrease significantly, as they depend on the current income of citizens. The advantage of deposits in the national currency is that they mainly offset the impact of inflation, but their liquidity (the ability to quickly transform into goods and services) on time deposits decreases sharply. Deposits in foreign currency can be both profitable and unprofitable, as it directly depends on the dynamics of the exchange rate, and the liquidity of funds in this form is slightly lower than deposits in national currency.

Despite the lowest wage rates of households in Ukraine, compared to EU countries, the value of the share of their savings is quite high, especially until 2013, but after the crisis of 2014 decreased significantly.

According to statistics from European countries, the highest value of the share of savings in income, as the level of wages is in households in Luxembourg (in 2017 $21.50 \%$, in $2018-21.41 \%$ ) and Germany in 2017-17.94\%, in $2018-18.54 \%$ ) [4]. The lowest values of the share of savings is in households of Lithuania (in $2017-0.29 \%$, in $2018-1.21 \%$ ), Poland (in $2017-2.79 \%$, in $2018-1.47 \%$ ) and Romania (in $2017-2.55 \%$, in $2018-0.78 \%$ ).

Another fairly popular tool for transforming household savings into investment resources is investing in housing construction.

The crisis of 2008 had a significant impact on the decline in this indicator, but in 2010 the population resumed investment in construction. In 2014, the crisis, the military conflict in eastern Ukraine led to a significant reduction in investment, and since 2015 there has been an increase in volume, and in 2019 amounted to 32422 million UAH, which is three times higher than in 2008, although they the share in the structure of capital investments remained almost unchanged at 5.2\%.

Conclusions. One of the priority areas for ensuring the development of the national economy in the post-crisis period is to increase the efficiency of the use of internal financial resources of all economic entities. Important participants in financial relations in Ukraine are households, which as economic entities form a strong investment potential, which not only ensures their livelihood, but also contributes to the development of economic processes of the state as a whole.

\section{References:}

1. Eurostat (2019). Household saving rate (indicator). Available at: https://ec.europa.eu/eurostat/databrowser/view/tec00131/ default/table?

2. Eurostat of Poland (2020). Household saving rate (indicator). Available at: https://ec.europa.eu/eurostat/databrowser/view/ tec00131/default/table?

3. The European Commission. Available at: https://ec.europa.eu/growth/sectors

4. The State Statistics Service of Ukraine (SSSU). Available at: http://ukrstat.gov.ua

5. National Financial Educators Council. Available at: https://www.financialeducatorscouncil.org/personal-finance-definition

6. The World bank statistics. Available at: https://bank.gov.ua/statistic/sector-financial/datasector-financial\#1ms 